\title{
THE RESEARCH OF THE LEADING POSITION OF A SMALL ENTERPRISE IN THE FIELD OF MARKET RELATIONS IN THE SPHERE OF IT SERVICES CONSIDERING THE FREELANCE RESOURCE
}

\author{
Tatiana Galahova' \\ Kyiv National Economic University named after Vadym Hetman, Ukraine \\ Katerina Fokina-Mezentseva ${ }^{2}$ \\ Kyiv National University of Technologies and Design, Ukraine
}

\begin{abstract}
The subject of research. IT enterprise activities and methods of staff quantity optimization under the terms of freelance resources attracting with the aim of taking leadership positions in the market for IT services. Methodology: during the research, the following scientific methods are used - the methods of analysis, synthesis, and comparative analysis (studying demand and supply of freelance-resource of small IT enterprises), the economic-statistical method (statistical analysis of empirical data, analysis of variation series of demand and supply distribution of freelance applications for a small IT enterprise). The purpose of scientific research: the purpose of the article is to provide theoretical justification for using freelance-resource within a small IT enterprise under the terms of freelance services demand and supply studying, which allows taking leading positions in the field of market relations in the sphere of IT services. The conclusion of the research: the calculation of the full-time employees' optimal quantity of small IT-company is made, which is the most important task of determining the reasonable need for staff to ensure the company's leading position in the field of market relations of IT services. The purpose of the paper is to the research the competitive advantages and a leading position of a small company in the dimension of global market relations in the field of services, which is determined the use of online freelanceresource by small IT enterprises. This approach belongs to the strategic management of expenditures of a small enterprise, which is the basis of the effective resources using a small enterprise and there is a prerequisite for establishing its leading position. The scientific achievements, which consider freelance-resource in the context of the export-oriented sphere of services as a new vector of the economic growth of Ukraine, are systematized; the author's approach to the definition of the category of "freelancers" and the consideration of the essence of freelance activity special features are presented. To determine the minimization of expenditures, the activity of a small IT enterprise is analysed, within which full-time employees are working, whose employment depends on the number of freelance-applications for jobs, which are receiving over a period of time for the IT enterprise needs. The statistical analysis of demand and supply within a small IT enterprise is proposed, which determines the optimal quantity of full-time employees who complete the technical tasks based on the freelance-resource, which enables a small IT enterprise to take a leading position in the field of market relations among similar small enterprises. Today, in the new concepts of the network economy and the global reputation economy, there are trends that represent an objective reflection of modern transformational changes in the economy, which are associated with the use of freelance-resource, which is an essential factor in establishing the leading positions of enterprises in competitive markets.
\end{abstract}

Key words: freelance resource, leading position, IT enterprise, variation distribution, demand, supply.

JEL Classification: M210, C20, L230

\footnotetext{
Corresponding author:

${ }^{1}$ Department of International Management, Kyiv National Economic University named after Vadym Hetman.

E-mail: tetyanagalakhova@gmail.com

${ }^{2}$ Department of Economics and Business, Kyiv National University of Technologies and Design.

E-mail: fok-mezentseva@ukr.net
} 


\section{Introduction}

Rapid globalization encourages new perspectives and, at the same time, creates new challenges in today's market conditions, both at the level of the individual, and on the micro, macro, meso, and global levels, covering all spheres of society's life, including the avantgarde and perspective sphere of IT technologies. In this context, a significant objective dynamic of technological and social innovations significantly changes parameters and the ratio of demand and supply in global markets. In the conditions of the development of globalization processes, the tendency of virtualization, innovation and informatisation of the economy, in particular, those activities that require a wide audience, is increasingly using electronic resources not only for information provision but also for realization of actual operations. In today's market conditions, global demand requires the most affordable international price, and the global offer seeks to ensure the formation of the price of such a format and its compliance with the global market situation. This mechanism ensures the functioning of all types of markets for goods and services, intellectual property objects, as well as identifies the latest trends in the labour market.

Dynamic development of the market of freelanceservices encourages the study of this phenomenon, because such a form of entrepreneurship is relatively new both in Ukraine and globally, and also corresponds to the current development of market relations. The freelance market of services is in demand and is currently being presented on a large scale and high rates of development in the United States and in a number of economically developed European countries. By adapting the best practices of doing business, the market of the freelance services of Ukraine and the CIS countries is rapidly developing, attracting more and more new members both from the side of the providers offering their services and from individuals and organizations willing to cooperate on a remote basis. In the freelance-market format, it is worth noting that the peculiarities of expenditures of a small enterprise as an object of management are their diversity, constant review and making changes under the influence of the external and internal environment, with varying intensity and dynamics. There is an actual issue of precise quantification of the level of expenditures, their magnitude and dynamics, the determination of the impact of expenditures on the economic performance of a small enterprise and the finding of new methods for their optimization. It should be noted that the effectiveness of planning and controlling the level of expenditures also depends on the timely provision of information on all levels of management by the expenditures of the enterprise. In this context, a research that combines the theory of the effective use of human resources and statistical analysis to interpret the process of implementing freelance-based services for IT operations in a small business is relevant.

\section{Literature review}

Advanced enterprises with leading positions in the global market use their own unique strategies based on innovative technological resources and business practices. The stated format of enterprise strategies creates global competitive advantages through the implementation of a proactive rather than a reactive vector of development, anticipating global challenges and forecasting, global change, generating fundamentally new market opportunities, occupying new segments of the market that competitors have not paid attention to.

According to O. Gudzinsky, S Sudomir, T. Gurenko (2010) the ability to upgrade, the realization of the way of modernization of production processes, search for new sources of competitive advantages allow enterprises to be competitive, to be leaders in their markets. At the same time, according to O. Maslyayeva (2011), competitors can take leading positions if the company ceases to improve and innovate. Consequently, the competitiveness of the company depends on the latest efficient resources, both own and borrowed, the implementation of effective business strategies, success in innovation activities, global openness.

It is interesting to study the scientists Katarzyna Sieradzka, Radosław Luft (2015), concerning the latest potential of the enterprise, which includes the following components: study and analysis of market conditions; demand and supply analysis; analysis of prospects of market development; analysis of economic activity and competitiveness of the enterprise; assessment of potential competitive opportunities of the enterprise; studying and evaluating the activities of competitor companies.

It should be noted that the research of the company's leading position in today's market conditions is realized both by domestic and foreign scientists. In this context, in order to achieve the strategic goals of the enterprise, it is necessary to distinguish freelance activity, which in the narrow sense implies the transfer of a part of the functions of the enterprise to the third persons. Today, "freelancer" is the most common and often used worldwide term that identifies independent IT professionals and is particularly common in such areas as computer programming and design in all its manifestations (advertising, web design, interior design etc.), translation from foreign languages, multi-sectoral consulting activities.

Note that in 2016,34\% of the working population of the United States was engaged in freelance activities. According to the forecasts of scientists by 2020, the number of freelancers will reach $50 \%$. According to a study by the European Forum of Independent 
Professionals (EFIP), since 2000, the number of freelancers in Europe has increased by $82 \%$. At the same time, the number of small IT enterprises is increasing in Ukraine and, as a result, the number of freelancers increases, with Ukraine ranked fourth in the world by their number after the USA, Russia, and India, according to O. Grishnova, O. Savchenko (2016).

Burke A. (2012) noted that "freelancers are employees who supply their services for potential projects or time-limited remuneration tasks that are directly proportional to the outcome of the work. They assume all or most of the expenditures and risks of their own idle time, as well as the risks of low expectations of performance within the projects. Freelancers assume all the costs and risks of economic inactivity between projects." According to H. Yoganarasimhan (2013), a freelancer is a person performing work without a long-term contract with the employer; that is, a freelance employee hired only to perform a certain list of works. Also, a freelancer is an employee who is invited to perform work during outstaffing. It is emphasized that being outside the permanent staff of any company, the freelancer can simultaneously execute orders for different clients.

Researchers T. Malone and J. Laubacher (1998) believe that freelancers are independent professionals who carry out their work remotely using information and communication technologies. S. Christopherson (2002) believes that the term "freelance" reflects the form of work on a contractual basis, self-organized work, which does not provide for a formally stable and continuous relationship with a single firm or employer.

J. Sapsed, R. Camerani, M. Masucci (2008) and others also point out that freelancers are a visible labour force, called differently as freelancers, contractors, consultants: self-employed agents of creative and digital growth. D. Gefen, E. Carmel (2012) suggest an expanded interpretation of the category of freelance in the information economy, as self-employment, labour autonomy, and the professional work of skilled professionals in the creative, managerial, scientific or technical spheres.

Since the late 1990s, the markets of remote work that operate in the online space are dynamically developing and connect freelancers and customers from all over the world, therefore, the phenomenon of "electronic self-employment" of professionals who are explored in the papers by H. Aguinis, T.V. Bludova, E.M. Galakhov (2017), S. Lawal, (2013). M. Leung (2014), J. Horton (2010), deserves special attention.

When engaging freelance resource, you need to study the supply and demand in the market. In the work by Q. Yao (2012), this research is explored in the logistics outsourcing network, in which small and mediumsized enterprises began to work actively, which became possible with the development of innovations.
N. Roshchina (2014) conducts a theoretical study of peculiarities of the formation of demand and supply in the market of resources, which, depending on the conditions, have individual features that determine the principles of its functioning. In Ukraine, more and more small businesses use outsourcing when support functions of business infrastructures are provided to external companies. Among the benefits of this approach is reducing IT costs, increasing the availability of IT services, and improving the quality of support.

Thus, an overview of scientific studies of domestic and foreign scientists allows suggesting that freelanceactivity is not sufficiently investigated in the context of modelling the effective use of freelance-resource at the enterprise from the standpoint of studying supply and demand, which will give a possibility to analyse the ability of a small IT enterprise to occupy a leading position in the field of market relations of IT services.

\section{The use of IT freelance to attract professionals}

Let us consider the activities of a small IT enterprise that specializes in developing and implementing software products for business automation, building integrated systems of information security, protecting consumer rights, electronic paperless document circulation, IT consulting and IT outsourcing, as well as system integration and infrastructure (see Gryshova I. Yu., Strielkowski W., Shcherbata M., 2017).

The use of IT freelance to attract professionals to develop and maintain software and computer technology of the enterprise is becoming a widespread phenomenon. When applying for freelance, the IT company expects that the delegated work is carried out not only on weekends but also at the hours outside the working hours.

Let us consider the IT company, which employs 14 full-time employees who are looking for and applying for freelance-resource for the needs of the company. The employment of these employees depends on the number of freelance applications for jobs received over a period of time (per year) for the needs of the IT enterprise.

It is necessary to calculate the optimal number of staff of IT enterprises so that the cost of organizing freelanceresource applications was minimal. Through the study of the number of hours required for a staff member of the company to search and register, the proposed freelance applications, statistics were obtained.

Thus, statistical data on the demand for work (the number of search and registration for freelanceapplications), required for IT company for 100 hours, as well as the frequency - the number of hours, during which the need for a staff member of the company to search and register freelance-applications, was recorded in the form of the following statistics: 
Table 1

Variation in the distribution of the demand for freelance applications

\begin{tabular}{|l|c|c|c|c|c|c|c|c|c|c|c|c|c|c|}
\hline $\begin{array}{l}\text { Demand for freelance- } \\
\text { applications }\end{array}$ & 4 & 5 & 6 & 7 & 8 & 9 & 10 & 11 & 12 & 13 & 14 & 15 & 16 & 130 \\
\hline Frequency & 2 & 4 & 4 & 8 & 10 & 12 & 12 & 12 & 10 & 10 & 8 & 6 & 2 & 100 \\
\hline
\end{tabular}

Source: Built by the authors on http://qvp.ua/uk/

Table 2

Calculation of indicators for the distribution of demand for freelance applications

\begin{tabular}{|c|c|c|c|c|c|c|}
\hline $\mathrm{xi}$ & Frequency, $\mathrm{fi}$ & $\mathrm{xi}^{*} \mathrm{fi}$ & $\begin{array}{c}\text { Accumulated } \\
\text { frequency, } \mathrm{S}\end{array}$ & $|\mathrm{x}-\mathrm{xcp}|^{*} \mathrm{fi}$ & $(\mathrm{x}-\mathrm{xcp}) 2^{*} \mathrm{fi}$ & Frequency, fi/f \\
\hline 4 & 2 & 8 & 2 & 12.64 & 79.885 & 0.02 \\
\hline 5 & 4 & 20 & 6 & 21.28 & 113.21 & 0.04 \\
\hline 6 & 4 & 24 & 10 & 17.28 & 74.65 & 0.04 \\
\hline 7 & 8 & 56 & 18 & 26.56 & 88.179 & 0.08 \\
\hline 8 & 10 & 80 & 28 & 23.2 & 53.824 & 0.1 \\
\hline 9 & 12 & 108 & 40 & 15.84 & 20.909 & 0.12 \\
\hline 10 & 12 & 120 & 52 & 3.84 & 1.229 & 0.12 \\
\hline 11 & 12 & 132 & 64 & 8.16 & 5.549 & 0.12 \\
\hline 12 & 10 & 120 & 74 & 16.8 & 28.224 & 0.1 \\
\hline 13 & 10 & 130 & 84 & 26.8 & 71.824 & 0.1 \\
\hline 14 & 8 & 112 & 92 & 29.44 & 108.339 & 0.08 \\
\hline 15 & 6 & 90 & 98 & 28.08 & 131.414 & 0.06 \\
\hline 16 & 2 & 32 & 100 & 11.36 & 64.525 & 0.02 \\
\hline Total & 100 & 1032 & & 241.28 & 841.76 & 1 \\
\hline
\end{tabular}

Source: calculated by the authors

- 4 freelance-applications for the design of web-design were completed within 2 hours;

- 5 applications for the layout of web pages and 6 applications for graphic design -4 hours,

- 7 applications for the ergonomics (usability) of the site - for 8 hours;

- 8 applications for adaptive web design - 10 hours;

- 9 applications for the use of flexible images (flexible images),

- 10 applications for creating a flexible layout, a gridbased layout.

- 11 applications of visual communications including orientation system - 12 hours;

- 12 applications of visiting sites and 13 applications of sites-quests - for 10 hours;

- 14 applications for creating promo sites - 8 hours;

- 15 applications for blog services - for 6 hours;

- 16 applications for the creation of product catalogues for 2 hours.

Thus, a variation in the distribution of the demand for freelance applications for a small IT enterprise was compiled (Table 1).

Table 2 presents the calculation of indicators for estimating a number of demand-sharing requests for freelance applications for a small IT enterprise.

Using the data in Table 2, we find the basic numerical characteristics: the sample mean $(10,32)$; the median (10), the range of the variation (12), the average linear deviation (2.41); dispersion (8.42), average square deviation (2.92).

\section{Calculating the relative variables of the variation}

Let us calculate the relative variables of the variation: the coefficient of variation $(28.11 \%)$, the linear coefficient of variation $(23.35 \%)$, the coefficient of oscillation (116.28\%), as well as the indicators of distribution: the central point of the third order $(-2.51)$ the coefficient of asymmetry $(-0,1-$ the presence of the left-hand side of the essential asymmetry), the excess (-0,73 - flat-panel distribution), the average square error of the coefficient of excess $(0,78$ - deviation from the normal distribution is not significant), the structural coefficient of the Pearson asymmetry $(0,11)$.

Table 3 shows the calculation of central moments. We find the confidence interval for the general average. Determine the value of tkp by the Student Distribution Table: Table $(n-1 ; \alpha / 2)=$ Ttabl $(99 ; 0.025)=1.984$. A standard sample error for the average (0.2916), marginal sample error (0.579). Then the confidence interval has the form:

$$
(10.32-0.579 ; 10.32+0.579)=(9.74 ; 10.9) \text {. }
$$

Thus, it can be argued that, with a probability of 0.95 , the average value for larger volumes will not exceed the range found.

Let us calculate the confidence interval for the dispersion. The probability of going beyond the lower bound is: $\mathrm{P}(\chi 2 \mathrm{n}-1<\mathrm{hH})=(1-\gamma) / 2=(1-0.99) / 2=0.005$. For the number of degrees of freedom $\mathrm{k}=99$, we find from the distribution table $\chi 2: \chi^{2}(99 ; 0.005)=140.1695$. 
Table 3

Calculation of the central moments for the distribution of demand for freelance applications

\begin{tabular}{|c|c|c|}
\hline$x_{i}$ & $\left(x-x_{c p}\right) 3^{*} f_{i}$ & $\left(x-x_{c p}\right) 4^{*} f_{i}$ \\
\hline 4 & -504.872 & 3190.791 \\
\hline 5 & -602.275 & 3204.103 \\
\hline 6 & -322.486 & 1393.141 \\
\hline 7 & -292.755 & 971.946 \\
\hline 8 & -124.872 & 289.702 \\
\hline 9 & -27.6 & 36.431 \\
\hline 10 & -0.393 & 0.126 \\
\hline 11 & 3.773 & 2.566 \\
\hline 12 & 47.416 & 79.659 \\
\hline 13 & 192.488 & 515.869 \\
\hline 14 & 398.688 & 1467.173 \\
\hline 15 & 615.019 & 2878.291 \\
\hline 16 & 366.501 & 2081.725 \\
\hline Total & -251.366 & 16111.523 \\
\hline
\end{tabular}

Source: calculated by the authors

We have a random error of the dispersion of the lower bound (6.01); the probability of exceeding the upper limit is 0.995 . For the number of degrees of freedom $\mathrm{k}=99$, we find the following distribution table $\chi^{2}: \chi^{2}$ $(99 ; 0.995)=67.32756$. We have a random error of the dispersion of the upper limit (12.5).

Consequently, the interval $(6.01 ; 12.5)$ covers the parameter $\mathrm{S} 2$ with reliability $\gamma=0.99$.

We find the confidence interval for the average-square deviation $(S(1-q)<\sigma<S(1+q))$ with the reliability $\gamma=$ 0 and the sample size $n=100$.

According to the table $\mathrm{q}=\mathrm{q}(\gamma ; \mathrm{n})$ we define the parameter $\mathrm{q}(0 ; 100)=0$ :

$2.92(1-0)<\sigma<2.92(1+0), 2.92<\sigma<2.92$.

Thus, the interval $(2.92 ; 2.92)$ covers the parameter $\sigma$ with reliability $\gamma=0$. The interval estimation of the general quotient (probability of the event).

We find the confidence interval for the general quotient $\left(\left(p^{*}-\varepsilon ; p^{*}+\varepsilon\right)\right)$. In this case, $2 F(t k p)=\gamma$, $\mathrm{F}(\mathrm{tkp})=\gamma / 2=0.954 / 2=0.477$. According to the Laplace function table, we find that tkp is the value of $\mathrm{F}(\mathrm{tkp})=0.477$ :

$\operatorname{tkp}(\gamma)=(0.477)=2$. With a probability of 0.954 , with a larger sample size, these quotients will be in the given intervals.

\section{Test hypothesis about the normal distribution}

Let us check the hypothesis that $\mathrm{X}$ is distributed in the normal law by means of the Pearson consistency criterion. To test the hypotheses about the type of distribution, we calculate the empirical frequencies given in Table 4.

Therefore, the critical area for this statistic is always right-handed: [Kkp; $+\infty)$. Its limit Kkp $=\chi^{2}(\mathrm{k}-\mathrm{r}-1 ; \alpha)$ is found according to the distribution tables $\chi^{2}$ and the given value $\sigma, \mathrm{k}=13, \mathrm{r}=2$ (the parameters $\mathrm{xcp}$ and $\sigma$ are estimated by the sample): $\operatorname{Kkp}(0.05 ; 10)=18.30704$; Ksost $=4.14$.

The observed value of Pearson's statistics does not fall into the critical area: Ksost $<\mathrm{Kkp}$, so there is no reason to reject the main hypothesis. Thus, it is fair to assume that the sample data for a number of requests for freelance demand for the IT business have a normal distribution.

\section{The distribution proposals of the suggested freelance applications by the IT enterprise}

Let us consider the statistical data of a number of distribution proposals of the suggested freelanceapplications by the IT enterprise, which were obtained by examining the number of hours during which the IT company forms proposals for the suggested freelance applications. Thus, the statistical data on the offer of freelance-claims generated by the company for 100 hours and the frequency or the member of hours, during

Table 4

Finding empirical frequencies and calculating values for the observed criterion of value

\begin{tabular}{|c|c|c|c|c|c|c|c|}
\hline $\mathrm{i}$ & $\mathrm{ui}$ & $\varphi \mathrm{i}$ & $\mathrm{n}_{\mathrm{i}}$ & $\mathrm{n}_{\mathrm{i}}^{*}$ & $\mathrm{n}_{\mathrm{i}}-\mathrm{n}_{\mathrm{i}}^{*}$ & $\left(\mathrm{n}_{\mathrm{i}}-\mathrm{n}_{\mathrm{i}}^{*}\right)^{2}$ & $\left(\mathrm{n}_{\mathrm{i}}-\mathrm{n}_{\mathrm{i}}^{*}\right)^{2} / \mathrm{n}^{*}{ }_{\mathrm{i}}$ \\
\hline 1 & -2.1783 & 0,0371 & 2 & 1.2787 & -0.7213 & 0.5202 & 0.407 \\
\hline 2 & -1.8337 & 0,0734 & 4 & 2.5299 & -1.4701 & 2.1612 & 0.854 \\
\hline 3 & -1.489 & 0,1315 & 4 & 4.5324 & 0.5324 & 0.2835 & 0.0625 \\
\hline 4 & -1.1443 & 0,2059 & 8 & 7.0968 & -0.9032 & 0.8158 & 0.115 \\
\hline 5 & -0.7996 & 0,2897 & 10 & 9.9851 & -0.01486 & 0.000221 & $2.2 \mathrm{E}-5$ \\
\hline 6 & -0.455 & 0,3589 & 12 & 12.3703 & 0.3703 & 0.1371 & 0.0111 \\
\hline 7 & -0.1103 & 0,3961 & 12 & 13.6525 & 1.6525 & 2.7306 & 0.2 \\
\hline 8 & 0.2344 & 0,3876 & 12 & 13.3595 & 1.3595 & 1.8482 & 0.138 \\
\hline 9 & 0.579 & 0,3372 & 10 & 11.6223 & 1.6223 & 2.632 & 0.226 \\
\hline 10 & 0.9237 & 0,2589 & 10 & 8.9236 & -1.0764 & 1.1587 & 0.13 \\
\hline 11 & 1.2684 & 0,1781 & 8 & 6.1386 & -1.8614 & 3.4648 & 0.564 \\
\hline 12 & 1.6131 & 0,1074 & 6 & 3.7018 & -2.2982 & 5.2818 & 1.427 \\
\hline 13 & 1.9577 & 0,0584 & 2 & 2.0129 & 0.01288 & 0.000166 & $8.2 \mathrm{E}-5$ \\
\hline$\Sigma$ & & & 100 & 100 & & & 4.136 \\
\hline
\end{tabular}

Source: calculated by the authors 
which the IT company forms the offer of freelance applications, are as follows:

- 5 freelance-applications for the Web Design construction that an IT Enterprise has formed within 1 hour;

- 6 applications for the layout of web pages - 3 hours;

- 7 applications for graphic design -4 hours,

- 8 applications for ergonomics (usability) of the site -

7 hours;

- 9 applications for adaptive web design - 11 years;

- 10 applications for the use of flexible images 12 hours;

- 11 applications for the creation of a grid-based layout,

11 applications for visual communications including the orientation system - 12 hours;

- 13 applications for visiting sites - 12 hours;

- 14 applications of quest sites - 11 years;

- 14 applications for the creation of promo sites -

7 hours; 16 applications for a blog service 5 hours;

- 16 applications for the creation of production catalogues -3 hours.

Thus, a variation of the distribution of the offer of freelance applications for a small IT enterprise was compiled (Table 5)

Table 6 presents the calculation of indicators for estimating the distribution of the offer of freelance applications for a small IT enterprise.

Table 5

Variation in the distribution of the offer of freelance applications

\begin{tabular}{|c|c|c|c|c|c|c|c|c|c|c|c|c|c|c|}
\hline Freelance Proposal & 5 & 6 & 7 & 8 & 9 & 10 & 11 & 11 & 13 & 14 & 14 & 16 & 16 & 140 \\
\hline Frequency & 1 & 3 & 4 & 7 & 11 & 12 & 12 & 12 & 12 & 11 & 7 & 5 & 3 & 100 \\
\hline
\end{tabular}

Source: Built by the authors on http://qvp.ua/uk/

Table 6

Calculation of indicators for the distribution of the offer of freelance applications

\begin{tabular}{|c|c|c|c|c|c|c|}
\hline$x i$ & Frequency, $f i$ & $x i{ }^{*} f i$ & Accumulated frequency, $S$ & $|x-x c p|^{*} i$ & $(x-x c p) 2^{*} f i$ & Frequency, fi/f \\
\hline 5 & 1 & 5 & 1 & 6.26 & 39.188 & 0.01 \\
\hline 6 & 3 & 18 & 4 & 15.78 & 83.003 & 0.03 \\
\hline 7 & 4 & 28 & 8 & 17.04 & 72.59 & 0.04 \\
\hline 8 & 7 & 56 & 15 & 22.82 & 74.393 & 0.07 \\
\hline 9 & 11 & 99 & 26 & 24.86 & 56.184 & 0.11 \\
\hline 10 & 12 & 120 & 38 & 15.12 & 19.051 & 0.12 \\
\hline 11 & 12 & 132 & 50 & 3.12 & 0.811 & 0.12 \\
\hline 11 & 12 & 132 & 62 & 3.12 & 0.811 & 0.12 \\
\hline 13 & 12 & 156 & 74 & 20.88 & 36.331 & 0.12 \\
\hline 14 & 11 & 154 & 85 & 30.14 & 82.584 & 0.11 \\
\hline 14 & 7 & 98 & 92 & 19.18 & 52.553 & 0.07 \\
\hline 16 & 5 & 80 & 97 & 23.7 & 112.338 & 0.05 \\
\hline 16 & 3 & 48 & 100 & 14.22 & 67.403 & 0.03 \\
\hline Total & 100 & 1126 & & 216.24 & 697.24 & 1 \\
\hline
\end{tabular}

Source: calculated by the authors

Using the data in Table 6, we find the basic numerical characteristics: selective average (11.26); the median (11), the variation (11), the average linear deviation $(2,162)$, the variance $(6,972)$, the average square deviation $(2,641)$.

Let us calculate the relative variables: the coefficient of variation $(23.45 \%)$, the linear coefficient of variation (19.2\%), the coefficient of oscillation (97.69\%), as well as the indicators of the distribution form: the central point of the third order $(-1)$, the coefficient of asymmetry $(-0,0541$ - the presence of left-sided non-essential asymmetry), excess (-0.73 - flat-panel distribution), excess (-0.65), structural coefficient of Pearson's asymmetry (0.0985).

Table 7 shows the calculation of the central moments. We find the confidence interval for the general average. We determine the value of tkp by the
Student Distribution Table: Table $(n-1 ; \alpha / 2)=$ Ttabl $(99 ; 0.025)=1.984$. The standard error sample for the average (0.2654), the marginal error of the sample (0.527). Then the confidence interval has the form:

$(11.26-0.527 ; 11.26+0.527)=(10.73 ; 11.79)$

Thus, it can be affirmed that, with a probability of 0.95 , the average value for larger volumes will not exceed the found range.

Let us calculate the confidence interval for the dispersion. The probability of going beyond the lower bound is: $\mathrm{P}(\chi 2 \mathrm{n}-1<\mathrm{hH})=(1-\gamma) / 2=(1-0.99) / 2=$ 0.005 . For the number of degrees of freedom $k=99$, we find from the distribution table $\chi 2$ :

$$
\chi^{2}(99 ; 0.005)=140.1695 \text {. }
$$

We have a random error of the dispersion of the lower bound (6.01); the probability of exceeding the upper 
Table 7

Calculation of the central moments for the distribution of the offer of freelance applications

\begin{tabular}{|c|c|c|}
\hline$x_{i}$ & $\left(x-x_{d} p\right) 3^{*} f_{i}$ & $\left(x-x_{c p}\right) 4^{*} f_{i}$ \\
\hline 5 & -245.314 & 1535.668 \\
\hline 6 & -436.595 & 2296.488 \\
\hline 7 & -309.235 & 1317.342 \\
\hline 8 & -242.522 & 790.621 \\
\hline 9 & -126.975 & 286.963 \\
\hline 10 & -24.005 & 30.246 \\
\hline 11 & -0.211 & 0.0548 \\
\hline 11 & -0.211 & 0.0548 \\
\hline 13 & 63.216 & 109.996 \\
\hline 14 & 226.279 & 620.005 \\
\hline 14 & 143.996 & 394.548 \\
\hline 16 & 532.482 & 2523.965 \\
\hline 16 & 319.489 & 1514.379 \\
\hline Total & -99.605 & 11420.331 \\
\hline
\end{tabular}

Source: calculated by the authors

limit is 0.995 . For the number of degrees of freedom $\mathrm{k}=99$, we find the following by the distribution table $\chi 2: \chi^{2}(99 ; 0.995)=67.32756$. We have a random error of the dispersion of the upper limit $(10,36)$.

Consequently, the interval $(4.97 ; 10.36)$ covers the parameter S2 with reliability $\gamma=0.99$.

We find the confidence interval for the average square deviation $(S(1-q)<\sigma<S(1+q))$ with the reliability $\gamma$ $=0$ and the sample size $\mathrm{n}=100$.

According to the table $\mathrm{q}=\mathrm{q}(\gamma ; \mathrm{n})$ we define the parameter $\mathrm{q}(0 ; 100)=0$ :

$$
2.654(1-0)<\sigma<2.654(1+0) 2.654<\sigma<2.654 \text {. }
$$

Thus, the interval $(2.654 ; 2.654)$ covers the parameter $\sigma$ with reliability $\gamma=0$. For the interval estimation of the general quotient (probability of the event), we find the confidence interval for the general quotient $\left(\left(p^{*}-\varepsilon\right.\right.$; $\left.\left.\mathrm{p}^{*}+\varepsilon\right)\right)$. In this case, $2 \mathrm{~F}(\mathrm{tkp})=\gamma, \mathrm{F}(\mathrm{tkp})=\gamma / 2=$ $0.954 / 2=0.477$. According to the Laplace function table, we find that tkp is the value of $\mathrm{F}(\mathrm{tkp})=0.477$ : $\operatorname{tkp}(\gamma)=(0.477)=2$. With a probability of 0.954 , with a larger sample size, these quotients will be in the given intervals.

Let us check the hypothesis that $\mathrm{X}$ is distributed in the normal law by means of the Pearson consistency criterion. To test hypotheses about the type of distribution, we calculate the empirical frequencies given in Table 8.

\section{Findings}

Therefore, the critical area for this statistic is always right-handed: $[\mathrm{Kkp} ;+\infty)$. Its limit Kkp $=\chi 2(\mathrm{k}-\mathrm{r}-1 ; \alpha)$ is found according to the distribution tables $\chi 2$ and the given value $\sigma, \mathrm{k}=13, \mathrm{r}=2$ (the parameters $\mathrm{xcp}$ and $\sigma$ are estimated by the sample): $\operatorname{Kkp}(0.05 ; 10)=18.30704$; Ksost $=4.14$. The observed value of Pearson's statistics does not fall into the critical area: Ksost $<\mathrm{Kkp}$, so there is no reason to reject the main hypothesis. Thus, it is fair to assume that the sample data of a number of requests of freelance demand for the IT business have a normal distribution.

Taking into consideration that the demand and supply of freelance applications have normal distribution laws, we choose the maximum value from the average sample: $\operatorname{Max}(10,32 ; 11,23)=11$, which is lower than the existing three units.

Thus, by analysing demand and supply, the calculation of the optimal number of full-time employees of a small IT enterprise is made, which is the most important task of determining the reasonable need for staff to ensure the company's leading position in the field of market relations of IT services.

\section{Conclusions}

The rapid development of globalization encourages new perspectives and, at the same time, creates new

Table 8

Finding empirical frequencies and calculating values for the observed value of criterion

\begin{tabular}{|c|c|c|c|c|c|c|c|}
\hline$i$ & $u_{i}$ & $\varphi_{i}$ & $n_{i}$ & $n_{i}^{*}$ & $n_{i}-n_{i}^{*}$ & $\left(n_{i}-n_{i}^{*}\right)^{2}$ & $\left(n_{i}-n_{i}^{*}\right)^{2} / n^{*}{ }_{i}$ \\
\hline 1 & -2.3707 & 0,0235 & 0.89 & 1.2787 & -0.11 & 0.01211 & 0.0136 \\
\hline 2 & -1.992 & 0,054 & 2.045 & 2.5299 & -0.955 & 0.9119 & 0.446 \\
\hline 3 & -1.6133 & 0,1074 & 4.067 & 4.5324 & 0.06736 & 0.00454 & 0.00112 \\
\hline 4 & -1.2346 & 0,1849 & 7.002 & 7.0968 & 0.00238 & $6.0 \mathrm{E}-6$ & $1.0 \mathrm{E}-6$ \\
\hline 5 & -0.8559 & 0,2756 & 10.437 & 9.9851 & -0.5627 & 0.3166 & 0.0303 \\
\hline 6 & -0.4772 & 0,3555 & 13.463 & 12.3703 & 1.4632 & 2.141 & 0.159 \\
\hline 7 & -0.09847 & 0,397 & 15.035 & 13.6525 & 3.0349 & 9.2104 & 0.613 \\
\hline 8 & -0.09847 & 0,397 & 15.035 & 13.3595 & 3.0349 & 9.2104 & 0.613 \\
\hline 9 & 0.659 & 0,3209 & 12.153 & 11.6223 & 0.1529 & 0.02337 & 0.00192 \\
\hline 10 & 1.0377 & 0,2323 & 8.797 & 8.9236 & -2.2025 & 4.8511 & 0.551 \\
\hline 11 & 1.0377 & 0,2323 & 8.797 & 6.1386 & 1.7975 & 3.2309 & 0.367 \\
\hline 12 & 1.7951 & 0,079 & 2.992 & 3.7018 & -2.0082 & 4.0328 & 1.348 \\
\hline 13 & 1.7951 & 0,079 & 2.992 & 2.0129 & -0.00818 & $6.7 \mathrm{E}-5$ & $2.2 \mathrm{E}-5$ \\
\hline$\Sigma$ & & & 100 & 100 & & & 4.144 \\
\hline
\end{tabular}

Source: calculated by the authors 
challenges in today's market conditions, covering all levels and areas of the society. With the approval of trends of virtualization, innovation, and informatisation of the economy, the parameters and the ratio of demand and supply on the global markets are radically changing, demanding the most affordable international price and opportunities to ensure the formation of the price of such a format and its compliance with the global market situation. Today, the freelance market as the newest global market, the advanced form of entrepreneurship, the modern format of relations between market subjects, is represented by largescale and high rates of development not only in the United States and economically developed countries of Europe but also within Ukraine and CIS countries. In the freelance-market format, the peculiarities of expenditures of a small enterprise as an object of management are their diversity, constant review and making changes under the influence of the external and internal environment, with varying intensity and dynamics. Therefore, the relevant question of precise quantification of the level of expenditures, their magnitudes and dynamics, determination of the impact of expenditures on the economic results of a small business and finding new methods for their optimization appears (see Gryshova, Zamlynskyi, Shestakovska, 2017). The presented methodology involves the calculation of the optimal number of the staff of IT enterprises so that the expenditures for organizing applications of freelance-resource were minimal. The presented study combines the theory of the effective use of human resources and statistical analysis for interpreting the process of implementing freelance services for IT operations in a small business. Thus, by analysing demand and supply, the calculation of the optimal number of full-time employees of a small IT enterprise is made, which is the most important task of determining the reasonable need for the staff in order to ensure the company's leading position in the field of market relations of IT services.

\section{References:}

Aguinis H., Lawal S. O. (2013). eLancing: ohlyad ta naukovo-doslidna robota dlya podolannya naukovo-praktychnoho rozryvu [eLancing: A Review and Research Agenda for Bridging the Science-Practice Gap]. Human Resource Management Review, vol. 23, iss. 1, pp. 6-17.

Gefen D., Carmel E. (2008). Chy diysno svit diysno ploskyy? Pohlyad na offshorynh v Internet-prohramuvanni [Is the World Really Flat? A Look at Offshoring in an Online Programming Marketplace]. MIS Quarterly, vol. 32, iss. 2, pp. 367-384.

Bludova T.V., Galakhov E.M. (2017). Modelyuvannya optymalnoho popytu na pozashtatni zastosuvannya IT-pidpryyemstva metodom Monte-Karlo [Modeling of optimal demand for freelance-applications of the IT enterprise by the Monte Carlo method]. Formation of market relations in Ukraine, no.9, iss.196, pp.53-59.

Bludova, T. V., Galakhov, E. M. (2017). Modelyuvannya propozytsiyi pozashtatnykh prohram IT-pidpryyemstva [Modeling the offer of freelance-applications of the IT enterprise. Formation of market relations in Ukraine], no.10, iss.197, pp. 60-66.

Burke, A. (2012). Rol frilanseriv u brytanskiy ekonomitsi 21 stolittya [The role of freelancers in the 21st century british economy]. Report, pp. 5-79. Retrieved from: http://pcg.drupal-staging.com/sites/default/files/media/ documents/RESOURCES/PCG\%20ANDREW\%20BURKE\%20REPORT\%20WEB.pdf

Christopherson, S. (2002). Robota proektu v konteksti: zmina rehulyuvannya ta nova heohrafiya zasobiv masovoyi informatsiyi. Navkolyshnye seredovyshche ta planuvannya [Project work in context: regulatory change and the new geography of media. Environment and Planning]. Environment and Planning A: Economy and Space, vol. 34, iss. 11, pp. 2003-2015.

Grishnova, O. A., Savchenko, O. O. (2016). Frilans: novi mozhlyvosti ta problemy realizatsiyi trudovoho potentsialu [Freelance: New Opportunities and Problems in Implementing Labor Potential]. Economy of Labor and Employment Problems, no.1, pp. 8-12.

Gryshova, I. Yu, Strielkowski, W, Shcherbata, M. (2017). Perekonlyvyy vydavnychyy ta vsebichnyy spysok: uroky dlya krayin, shcho adaptuyut novi kryteriyi otsinky doslidzhen [Predatory publishing and beall's list: lessons for the countries adapting novel research evaluation criteria]. Science and education, no. 8, pp. 39-43.

Gryshova, I. Yu., Zamlynskyi, V. A., Shestakovska, T. L. (2017). Vprovadzhennya klasternykh form u natsionalnu stratehiyu rozvytku osvity [Implementing Cluster Forms Into National Education Development Strategy]. Science and education, no. 5, pp. 56-61.

Gudzinsky, O. D., Sudomir, S. M., Gurenko, T. O. (2010). Upravlinnya formuvannyam konkurentnoho potentsialu pidpryyemstv (teoretyko-metodolohichnyy aspekt): monohrafiya [Management of the formation of competitive potential of enterprises (theoretical and methodological aspect): monograph]. Institute for the Training of Personnel of the State Employment Service of Ukraine. Kiev, IPK DSZU, 212 p.

Horton, J. (2010). Internet-rynky pratsi [Online Labor Markets]. Internet and Network Economics ,A. Saberi (ed.). Berlin; Heidelberg: Springer Berlin Heidelberg, vol. 6484, pp. 515-522.

Katarzyna Sieradzka, Radosław Luft (2015). Teoretychni aspekty konkurentospromozhnosti pidpryyemstva [Theoretical aspects of enterprise competitiveness]. Central European Review of Economics \& Finance, vol. 10, no. 4, pp. 133-141. 
Kitching, J., Smallbone, D. (2012). Chy ye frilansery vidmova vid maloho biznesu? [Are Freelancers a Neglected Form of Small Business?] Journal of Small Business and Enterprise Development, vol. 19, no. 1, pp. 74-91.

Leung, M. D. (2014). Dyletant abo osoba Renesansu? Yak poryadok dosvidu roboty vplyvaye na naym na zovnishnomu rynku pratsi [Dilettante or Renaissance Person? How the Order of Job Experiences Affects Hiring in an External Labor Market]. American Sociological Review, vol. 79, no. 1, pp. 136-158.

Malone, T. W., Laubacher J. (1998). Zir ekonomiky elektronnoyi ekonomiky [The dawn of the e-lance economy] Harvard Business Review, vol. 76, no. 5, pp. 144-153.

Maslyaeva, O. (2014). Ekonomichna sutnist katehoriyi "Konkurentospromozhnist": vyznachennya ta systematyzatsiya [The economic essence of the category "Competitiveness": Definition and systematization]. Effective economy, no. 10, accessed March 20. Retrieved from: http://economy.nayka.com.ua/index.php.

Roshchina, N. V. (2014). Upravlinnya vytratamy v systemi otsinky efektyvnosti diyalnosti pidpryyemstv promyslovosti [Cost Management in the System for Assessing the Efficiency of Industrial Enterprises Activity]. Economic Bulletin of NTUU "KPI", no. 11, pp. 216-221.

Xu Y., Yao Q. (2012). Doslidzhennya lohistychnoho autsorsynhu rozdribnoho merezhevoho pidpryyemstva na osnovi vidpovidnosti mizh propozytsiyeyu ta popytom [Research on Logistics Outsourcing of Retail Chain Enterprise Based on Fit between Supply and Demand]. In: Zeng D. (eds). Advances in Computer Science and Engineering. Advances in Intelligent and Soft Computing, Springer, Berlin, Heidelberg, vol. 141 pp. 619-625.

Yoganarasimhan, H. (2013). Znachennya reputatsiyi v internet-frilansernomu rynku [The Value of Reputation in an Online Freelance Marketplace]. Marketing Science, vol. 32, no. 6, pp. 860-891. 